\title{
Agreement between optical coherence tomography and fundus fluorescein angiography in post-cataract surgery cystoid macular edema
}

\author{
Concordância entre tomografia de coerência óptica e angiofluoresceinografia no \\ edema macular cistóide secundá rio a cirurgia decatarata
}

\author{
Somaia Mitne ${ }^{1}$ \\ Aug'usto Paranhos Júnior ${ }^{2}$ \\ Ana Paula Silvério Rodrigues ${ }^{3}$ \\ Tércio Guia ${ }^{4}$ \\ Arnaldo Bordon 5 \\ Nilva Simeren Bueno de Moraes ${ }^{6}$ \\ Michel Eid Farah ${ }^{7}$ \\ Pedro Paulo Bonomos
}

\section{ABSTRACT}

Purpose: To evaluate the agreement between optical coherence tomography (OCT) and fundus fluorescein angiography (FFA) regarding the detection of cystoid macular edema (CME) following cataract surgery. Methods: Retrospective comparative observational series of 25 eyes with suspected CME. Patients with low visual acuity and alterations in fundus biomicroscopy after cataract surgery underwent OCT scanning followed by FFA on the same visit. The diagnosis of CME was established considering fluorescein leakage on FFA and retinal thickness and/or cystoid spaces and/ or subretinal fluid on OCT. Results: Twenty-five eyes of 25 patients were enrolled. Twenty-two eyes had similar results on both OCT and FFA, of which 15 eyes had CME and 7 eyes had no CME. Two eyes had CME detected only by FFA and one eye only by OCT. The agreement between the two examinations was good $($ Kappa $=0.7331 ; \mathrm{p}=0.0001)$ with no tendency to have neither more positive nor negative findings $(p=1.0)$. Conclusion: According to these preliminary data, OCT seems to be as effective as FFA to detect CME with a good agreement between the two techniques.

Keywords: Macular edema, cystoid/diagnosis; Cataract extraction; Fluorescein angiography/methods; Tomography/methods; Comparative study

Paulo - UNIFESP.

Estagiária do Setor de Trauma Ocular, Chefe de plantão do Pronto Socorro de Oftalmologia da Universidade Federal de São Paulo - UNIFESP.

${ }^{2}$ Mestre e Doutor em Medicina, Chefe do Setor de Glaucoma da Universidade Federal de São Paulo-UNIFESP.

${ }^{3}$ Estagiária do Setor de Catarata da Universidade Federal de São Paulo - UNIFESP.

${ }^{4}$ Tecnólogo Chefe do Setor de Documentação Fotográfica da Universidade Federal de São Paulo - UNIFESP.

Mestre em Medicina pela Universidade Federal de São Paulo - UNIFESP.

${ }^{6}$ Chefe do Setor de Trauma Ocular e Pronto Socorro de Oftalmologia da Universidade Federal de São Paulo UNIFESP.

Professor Livre-Docente Adjunto de Oftalmologia da Universidade Federal de São Paulo - UNIFESP.

${ }^{8}$ Professor Adjunto de Oftalmologia da Universidade Federal de São Paulo - UNIFESP.

Endereço para correspondência: Rua Botucatu, 822 -

São Paulo (SP) CEP 04023-062

E-mail: somaia@oftalmo.epm.br

Recebido para análise em 20.05.2002

Versão revisada recebida em 20.06.2003

Aprovação em 16.09.2003

\section{INTRODUCTION}

The earliest recognition of macular edema as a complication of ocular surgery was in 1953, when Irvine ${ }^{(1)}$ described a syndrome of reduced central vision after intracapsular cataract extraction. In 1966, Gass and Norton ${ }^{(2)}$ described the characteristic fluorescein angiographic features of this syndrome, called cystoid macular edema (CME).

Postoperative CME remains a well-recognized complication following cataract surgery. It is the most common cause of decreased vision in patients following cataract surgery with or without the implantation of an intraocular lens ${ }^{(3)}$. CME more often is associated with complicated cataract surgery, particularly with rupture of the posterior capsule and vitreous loss, vitreous incarceration in the surgical wound, or a poorly positioned intraocular lens.

The incidence varies based on the definition of CME: angiographic CME in about $20-30 \%$ of uncomplicated surgeries, with classic petaloid pattern and no visual loss; and the second one is clinical CME in 1-6.9\% of the cases, with the same leakage and VA 20/40 or worse ${ }^{(4)}$.
} 
CME is caused by an accumulation of fluid in the outer plexiform layer and inner retinal layers of the perifoveal region - whether in swollen and degenerating Muller cells or as extracellular cysts. Because of this anatomy, fundus fluorescein angiography (FFA) shows leakage of dye in a classical "flower-petal" pattern.

FFA is the most widely used method to confirm the presence of $\mathrm{CME}^{(5)}$. It is an invasive test, with side effects ranging from nausea (up to 20\%) to its rare complication, anaphylaxis and death ${ }^{(5-7)}$. FFA is typically used to assess vascular leakage qualitatively, but it is actually macular thickening that better correlates with loss of visual acuity ${ }^{(8)}$.

Traditional methods of evaluating macular thickening including slit-lamp biomicroscopy, stereo fundus photography, are relatively insensitive. Thus, new techniques for quantitatively measuring retinal thickness have been explored ${ }^{(9)}$.

Optical coherence tomography (OCT) is a new technology that gives cross-sectional imaging of the retina. Imaging with OCT is analogous to ultrasound B-scan. The use of optical rather than acoustic waves, however, provides much higher resolution of the retina. Theoretically this resolution is of the order of $10 \mu \mathrm{m}$, but in a clinical setting it is approximately $15-20 \mu \mathrm{m}^{(10)}$. It has been shown to have a high degree of reproducibility in measuring macular thickness in normal individuals and diabetic patients ${ }^{(9)}$. It is noninvasive, comfortable, safe, and can be repeated as often as required.

Our purpose was to evaluate the agreement between OCT and FFA in the detection of CME after cataract extraction.

\section{METHODS}

We recruited 25 patients with suspected CME after cataract surgery at the Ophthalmology Department, UNIFESPEPM, between March 2001 and December 2002. The inclusion criteria were: low visual acuity $(\leq 20 / 40)$ and suspicious biomicroscopy (loss of foveal light reflex, loss of foveal depression, appearance of a yellowish spot deep in the foveal area, and cystoid spaces). Patients with previous ocular diseases such as uveitis, glaucoma, retinopathies and systemic diseases like diabetes, arterial hypertension, renal failure were not included in this study.

All patients underwent OCT 2 scanning (OCT, Zeiss Humphrey Systems, Dublin, CA) at 0, 45, 90 and 135 degrees centered on fixation (linear scans). The diagnosis of CME by the OCT was performed considering: retinal thickness, cystoid spaces and subretinal fluid (SRF).

Fluorescein angiograms (Topcon IMAGE net ${ }^{\circledR}$ system, 1024 lines resolution) were taken on the same visit subsequent to intravenous injection of $5 \mathrm{ml} 20 \%$ sodium fluorescein. Photographs were analyzed at approximately $10 \mathrm{~min}^{(1,5,11)}$ and the diagnosis was established considering incomplete 360-degree, mild to severe perifoveal hyperfluorescence.

All angiograms were analyzed by a retina specialist who was masked to the OCT findings.
The agreement between the two examinations was evaluated using the Kappa test. The tendency of disagreement was analyzed by the Mc Nemar test ${ }^{(12)}$.

\section{RESULTS}

A summary of the results is shown in Tables 1 and 2. We examined a total of 25 eyes. Table 1 presents the agreement between OCT and FFA considering subretinal fluid as part of the diagnosis of CME: 22 eyes had similar results on both examinations, of which 15 eyes had CME and 7 eyes had no CME. Two eyes had CME detected only by FFA and one eye only by OCT. The agreement between the two examinations was good (Kappa $=0.7331 ; \mathrm{p}=0.0001)$ with diagonal concordance of $88 \%$ and no tendency to have neither more positive nor negative findings $(\mathrm{p}=1.0)$.

On the other hand, Table 2 shows the agreement between OCT and FFA not considering subretinal fluid as part of the diagnosis of CME, but predominantly cystoid spaces: 20 eyes had similar results on both examinations, of which 12 eyes had $\mathrm{CME}$ and 8 eyes had no CME. Five eyes had CME detected only by FFA. The agreement between the two examinations was fair (Kappa $=0.6057 ; \mathrm{p}=0.0005)$ with diagonal concordance of $73 \%$.

\section{DISCUSSION}

Fluorescein angiogram is the gold standard method for the diagnosis of CME. However, even experienced clinicians are unable to read up to $15 \%$ of these angiograms owing to reflections, synechiae, poorly dilated pupils, vitreous haze, and others. In some of these conditions, it is possible to perform $\mathrm{OCT}^{(1)}$. FFA is also an invasive test, with side effects ranging from nausea (up to 20\%) to its rarest complication, anaphyla-

\begin{tabular}{|lcc|}
\hline \multicolumn{2}{|c|}{$\begin{array}{c}\text { Table 1. Agreement between OCT and FFA considering SRF as part } \\
\text { of the diagnosis of CME }\end{array}$} \\
\cline { 2 - 3 } & OCT \\
FFA & 15 & Nos \\
Yes & 1 & 2 \\
No & 7 \\
Kappa=0.7331; $p=0.0001 ;$ OCT: optical coherence tomography; FFA: fundus \\
fluorescein angiography; SRF: subretinal fluid
\end{tabular}

\begin{tabular}{|c|c|c|}
\hline \multirow[b]{2}{*}{ FFA } & \multicolumn{2}{|c|}{ OCT } \\
\hline & Yes & No \\
\hline Yes & 12 & 5 \\
\hline No & 0 & 8 \\
\hline \multicolumn{3}{|c|}{$\begin{array}{l}\text { Kappa }=0.6057 ; p=0.0005 ; \text { OCT: optical coherence tomography; FFA: fundu } \\
\text { fluorescein angiography; SRF: subretinal fluid }\end{array}$} \\
\hline
\end{tabular}


xis and death ${ }^{(5-7)}$. Therefore it is important to have alternative noninvasive methods such as OCT. To the best of our knowledge, there is no report in the literature regarding comparison between these two methods in the detection of cystoid macular edema after cataract surgery.

There is agreement that angiograms are of great value to confirm the presence or absence of CME, but the degree of leakage does not always correlate with the visual acuity ${ }^{(8)}$. An angiogram documents fluid in cystoid spaces in the outer plexiform layer, but decreased vision may be associated with edema in the photoreceptor area or elsewhere. Previous studies showed a significant relationship between the estimation of visual acuity and macular thickening, which could be measured objectively using $\mathrm{OCT}^{(8-9)}$. As our study was a retrospective one, we missed precise information regarding visual acuity. As we have only categorical data (VA worse than 20/40), we did not perform any analysis with these data.

The OCT images with CME closely corresponded to known histopathologic features. Figure 1B shows an OCT scan obtained through the macula providing three-dimensional information on retinal structure and the corresponding FA displays late leakage in the fovea in a petalloid pattern (Figure 1A). Minimally reflective spaces can be identified in the outer retinal layers corresponding to cystic changes, and large central cysts can be noted to extend almost to the inner limiting
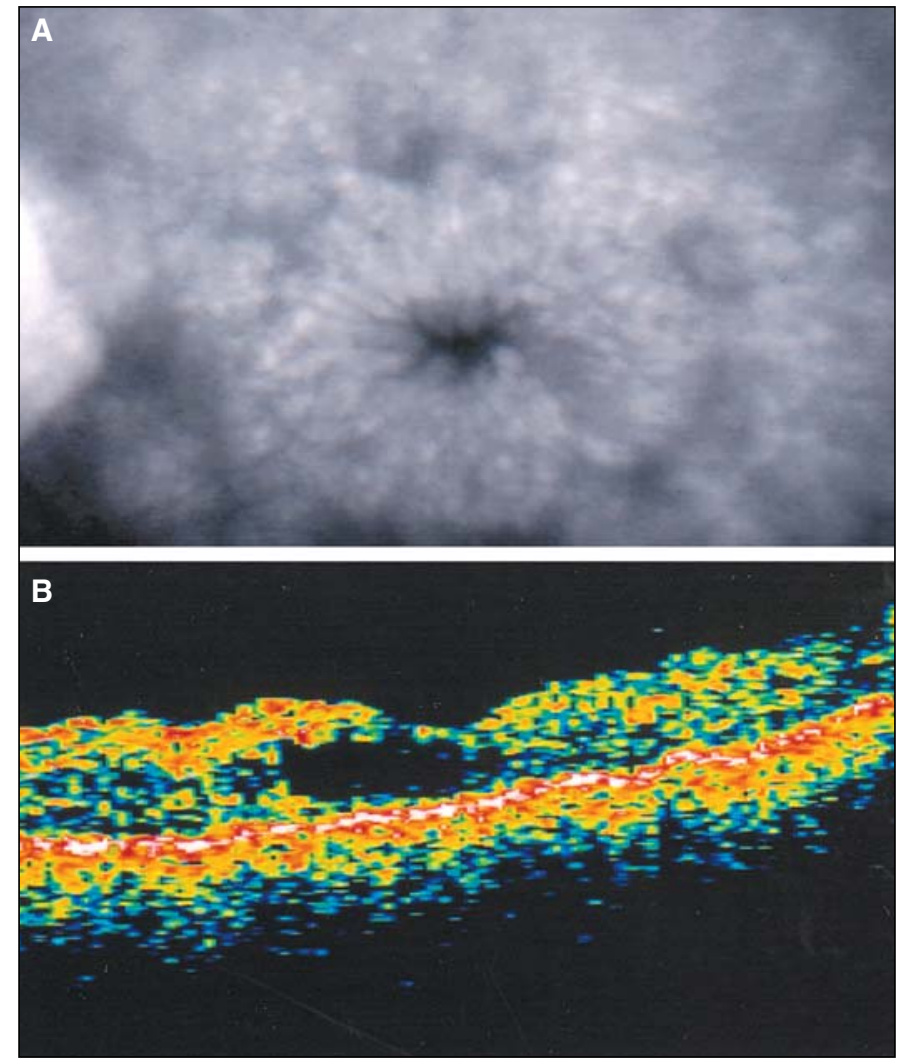

Figure 1 - A: Fluorescein angiogram demonstrating late leakage in a petalloid pattern consistent with cystoid macular edema and B: multiple cysts in the correspondent OCT scan membrane $^{(9)}$. In figure 2B an OCT cross section shows a cyst directly in the fovea and a loss of the normal contour of the fovea pit and the corresponding FA with 360-degree of hyperfluorescence consistent with CME (Figure 2A).

The reduced optical reflectivity was caused by SRF accumulation which was detected in the 5 eyes with negative OCT results (Table 2 ). This probably happened because mild leakage on FFA could not lead to cystoid space collections on OCT, with adequate retinal compensatory mechanisms. This fact emphasizes the importance of considering also SRF by OCT in the CME diagnosis (Table 1), in order to get higher agreement. Figure 3B shows minimally reflective spaces corresponding to fluid accumulation in the outer retinal layers and the corresponding FA with mild hyperfluorescence (Figure $3 \mathrm{~A})$. On the other hand, a possible explanation for the one case (Table 1) with only OCT positive result, could be a transitory leak that has already ceased and would not show on FFA, but a fluid space may still be present before compensatory mechanisms have removed $i^{(5)}$. Further studies should be performed to assess whether OCT is more sensitive than FFA in these cases.

According to our study, OCT is as effective as FFA at detecting CME after cataract surgery, when SRF was considered for the diagnosis.
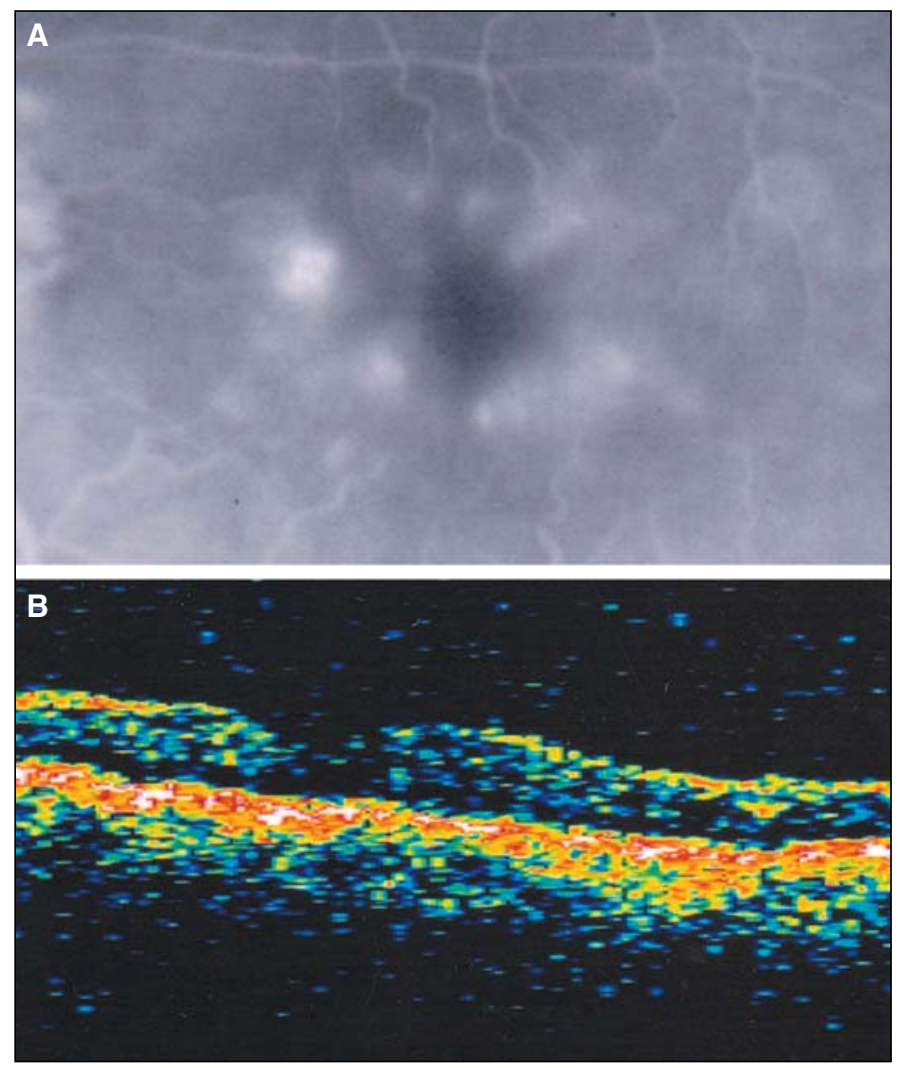

Figure 2 - A: Fluorescein angiogram showing 360-degree of hyperfluorescence and $\mathrm{B}$ : one dominant cyst image in the corresponding OCT scan 

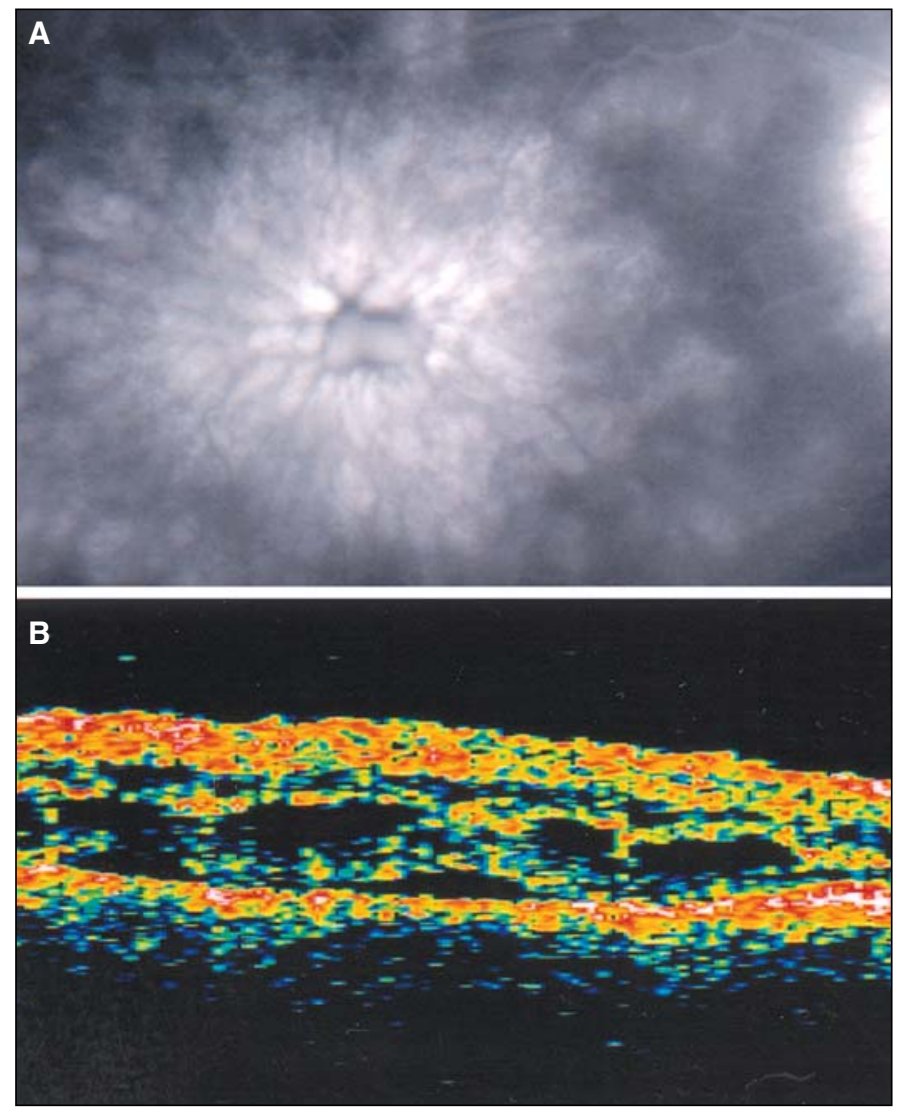

Figure 3 - A: Fluorescein angiogram showing mild hyperfluorescence with B: predominantly SRF in the OCT scan

\section{RESUMO}

Objetivo: Avaliar a concordância entre tomografia de coerência óptica (OCT) e angiofluoresceinografia (AF) no diagnóstico do edema macular cistóide (EMC) secundário a cirurgia de catarata. Métodos: Estudo retrospectivo observacional comparativo de 25 olhos com provável EMC. Pacientes com baixa de acuidade visual e alterações na biomicroscopia de fundo após cirurgia de catarata foram submetidos aos exames de OCT e AF na mesma visita. O diagnóstico do EMC foi realizado considerando a presença de vazamento de fluoresceína na angiografia e o espessamento retiniano e/ou espaços cistói- des e/ou líquido subretiniano pela OCT. Resultados: Vinte e cinco olhos de 25 pacientes foram avaliados. Vinte e dois olhos mostraram resultados semelhantes no OCT e AF, sendo que 15 olhos apresentaram EMC e 7 olhos não apresentaram EMC. Dois olhos com EMC foram diagnosticados apenas pela AF e um olho apenas pelo OCT. A concordância entre os exames foi boa (Kappa $=0,7331 ; p=0,0001$ ) sem tendência para achados positivos ou negativos $(\mathrm{p}=1,0)$. Conclusão: Conforme este estudo preliminar, OCT parece ser tão efetiva quanto a AF na detecção do EMC com boa concordância entre os dois métodos.

Descritores: Edema macular cistóide/diagnóstico; Extração de catarata; Angiofluoresceinografia/métodos; Tomografia/ métodos; Estudo comparativo

\section{REFERENCES}

1. Irvine SR. A newly described vitreous syndrome following cataract surgery, interpreted according to recent concepts of the structure of the vitreous. Am J Ophthalmol 1953;35:599-619.

2. Gass JDM, Norton EWD. Cystoid macular edema and papilledema following cataract extraction: a fluorescein fundoscopic and angiographic study. Arch Ophthalmol 1966;76:646-61.

3. Flach AJ. The incidence, pathogenesis and treatment of cystoid macular edema following cataract surgery. Trans Am Ophthalmol Soc 1998;96:557-634.

4. Heier JS, Topping TM, Baumann W, Dirks MS, Chern S. Ketorolac versus prednisolone versus combination therapy in the treatment of acute pseudophakic cystoid macular edema. Ophthalmology 2000;107:2034-9.

5. Antcliff RJ, Stanford MR, Chauhan DS, Graham EM, Spalton DJ, Shilling JS, et al. Comparison between optical coherence tomography and fundus fluorescein angiography for the detection of cystoid macular edema in patients with uveitis. Ophthalmology 2000;107:593-9.

6. Schatz H, Farkos WS. Nausea from fluorescein angiography. Am J Ophthalmol 1982;93:370-1.

7. Yannuzzi LA, Rohrer KT, Tindel LJ, Sobel RS, Costanza MA, Shields W, et al. Fluorescein angiography complication survey. Ophthalmology 1986;93: 611-7.

8. Nussenblatt RB, Kaufman SC, Palestine AG, Davis MD, Ferris FL. $3^{\text {rd }}$ Macular thickening and visual acuity. Measurement in patients with cystoid macular edema. Ophthalmology 1987;94:1134-9.

9. Hee MR, Puliafito CA, Wong C, Duker JS, Reichel E, Rutledge B, et al. Quantitative assessment of macular edema with optical coherence tomography. Arch Ophthalmol 1995;113:1019-29.

10. Brancato R. Optical coherence tomography in macular edema. Doc Ophthalmol 1999;97:337-9.

11. Yannuzzi LA. A perspective on the treatment of aphakic cystoid macular edema. Surv Ophthalmol 1984;28(Suppl):540-3.

12. Armitage P, Berry G. Statistical methods in medical research. $3^{\text {rd }}$ ed. Oxford: Blackwell Science;1994. p.402-47.

\section{Nos artigos enviados para publicação, o nome dos autores e suas afiliações devem estar completos. Isso facilitará a indexação e os links com as bases de dados e o CV Lates.}

